\title{
Role of Social Media on Information Accessibility
}

\author{
Farzana Parveen Tajudeen \\ Department of Operations and Management Information Systems \\ Faculty of Business \& Accountancy \\ University of Malaya, Malaysia, \\ farzanatajudeen@um.edu.my \\ Noor Ismawati Jaafar \\ Department of Operations and Management Information Systems \\ Faculty of Business \& Accountancy \\ University of Malaya, Malaysia \\ isma jaafar@um.edu.my \\ Ainin Sulaiman \\ Department of Operations and Management Information Systems \\ Faculty of Business \& Accountancy \\ University of Malaya, Malaysia \\ ainins@um.edu.my
}

\begin{abstract}
Social media is the gathering place of a large pool of consumers. It is the repository of consumer information and acts as a means of spreading information to build market presence. Most literature states that organizational usage of social media enhances customer relations, but social media also acts as a medium for information acquisition. Not many previous studies have investigated the role of social media on information accessibility. Therefore this study examined the impact of social media on information accessibility. A total of 171 organization responded to the survey and the result of the survey showed that social media usage has a positive impact on information accessibility. Also it was found that factors such as interactivity, trust and institutional pressure positively influence social media usage in organizations. This study provided a clearer understanding on the real importance of social media and its benefits towards information acquisition. The results would motivate and guide organizations in social media usage for information acquisition which is important for understanding the customers, competitors and the industry and to develop strategies for enhancing business performance.
\end{abstract}

Keywords: Social media, Information accessibility, Organizational impact, Customer relations 


\section{Introduction}

Organizations are using social media to improve their social network salience, enhance interest in their organizations, and build relationships with the online public. The relationship developed through social media not only brings customers closer to the organization but also helps organizations to get more information about the market trends, customer's needs and wants (Parveen et al., 2015). These benefits associated with social media makes it grow as an important strategic tool among organizations (Gomez Vasquez and Soto Velez, 2011). Regardless of the existing debate on advantages and disadvantages of social media, investments in these technologies are growing high (LeaderChivée and Cowan, 2008). A survey by the McKinsey Quarterly on the implementation of Web 2.0 in the business sector showed that more than $75 \%$ of organizations planned to maintain or increase their investments in Web 2.0 (Chu et al., 2011). So in this case, it is important to know the benefits associated with social media usage in organizations.

Even though investments in these technologies are growing high, the most important thing is that organizations must use social media effectively and strategically to gain its full potential. For the organizations to use social media effectively there should be certain factors that influences and supports the usage in organizations. Therefore this study identifies the factors that influence social media usage among organizations. Furthermore, academic research that investigates the impact of social media on organizations is quite limited (Schultz et al., 2012). Generally the social media usage in organizations are related to the enhancement of relationship with customers but one of the most important impacts of social media usage is the improvement in information accessibility; the organizations can easily obtain the information about their potential customers, their tastes, their wants from the conversations on social media sites. Organizations can also obtain information about the activities, brand sentiments and tactics of their competitors by becoming fan of the Facebook pages of their competitors. Organizations can also gather general information about the market, new trends and industry information through social media. Moreover, organizations can also easily deliver the organizational information to the public in a timely manner (Parveen et al., 2015). However, not many previous studies have investigated the impact of social media on information accessibility. Therefore this study attempts to fill up this gap. The following section presents the literature review and the theoretical underpinnings of the study. Subsequently, the methods used to conduct the study are explained which is then followed by the description of the data analysis, findings and discussion.

\section{Literature Review}

Social media covers a wide variety of webbased technologies that enable users to contribute to, as well as consume information. These social media tools can be established anywhere with an Internet connection, and it should be considered by marketers, advertisers, and content creators as a basic part of their communications because social media affects all aspects of the Internet and transforms the role of the Internet in people's lives (Akar and Topcu, 2011; UnicersalMcCann, 2008). Organizations should consider using social media mainly because of the changing trends among consumers. According to Mangold and Faulds (2009), marketing managers should recognize the power and critical nature of the discussions that is being carried on by consumers via social media. They illustrated the nature of the current trend as that the Internet has become a mass media vehicle for consumer-sponsored communications. It now represents the number one source of media for consumers at work and the 
number two source of media at home (Rashtcy et al., 2007). As the trend is changing more favorably towards social media among consumers, social media also provides various advantages to organizations.

Social media can assist organizations to create an online resource containing the accumulated wisdom of the organization, by allowing knowledge to be codified, searched, and shared (Cairncross, 2001; IBM, 2007). Organizations can gain information about their consumers and their target markets which enable them to produce and tailor the goods and services according to the customer needs. More and more often, businesses are investing in resources that integrate social data into their existing customer database information as part of customer relationship management (CRM) upgrades (Trainor, 2012; VanBoskirk et al., 2011). As it can be seen social media is a growing phenomenon and perhaps the latest user-led innovation to emerge from the World Wide Web and Web 2.0 technologies. However, research on the organizational use of social media is new and few (Akar and Topcu, 2011). Therefore this study aims to identify the factors influencing social media usage and its subsequent impact on informational accessibility of the organizations.

Figure 1 outlines the theoretical model that guides this research. The research model for this study is based on the technology, organization, and environment (TOE) framework. The model also combines the aspect of resource based view theory, institutional theory, and the DeLone and McLean IS success model. Tornatzky and Fleischer (1990) developed the TOE framework to evaluate technology adoption. The framework identifies three aspects of a firm's characteristics namely technological, organizational and environmental. These characteristics influence the process of adopting, implementing and using technological innovations (DePietro et al., 1990; Robertson, 2005; Tornatzky and Fleischer, 1990). Factors relating to technological, organizational, and environmental context were examined to identify its influence on social media usage in organizations. During the initial stage of the study, the factors associated with social media usage were identified through interviews. The interviews were conducted among senior managers of the organizations that are using social media. Then, after referring to the literature, the research model for the study was developed by mapping the identified factors to TOE framework. Moreover, based on the DeLone and McLean IS success model, the relationship between social media usage and organizational impact were examined.

\section{Interactivity and Social Media Usage}

Under technological context, previous studies have investigated the characteristics of the technology such as compatibility, complexity and relative advantage and its impact on technology usage (Low et al., 2011; Ramdani et al., 2009). In this study, interactivity which is one of the unique characteristics of social media technology has been examined to find its impact of social media usage in organizations. Technologies are perceived to possess attributes that have effect on the decision to use and how they will be implemented. Previous studies have found that the design and implementation of the computing systems considers the successful interaction between a human and a computer as a key factor (Lee and Kozar, 2012). Among the various design characteristics, interactivity stands out as a key and distinguished factor that impacts users' response to new technologies including websites (Agarwal and Venkatesh, 2002; Jiang and Benbasat, 2007). Social media is considered as an interactive media. It enables two-way communication rather than one-directional transmissions or distributions of information to an audience (Mayfield, 2008). E-business sites have rushed to integrate these social networking features into their websites, enabling enhanced interactive communications between consumers or between consumers 
and organizations (Lee and Kozar, 2012). Adding social networking features also augments site credibility. Therefore, considering the interactive nature of social media, this study investigates the influence of interactivity on the usage of social media in organizations.

H1: Interactivity of social media positively influences social media usage.

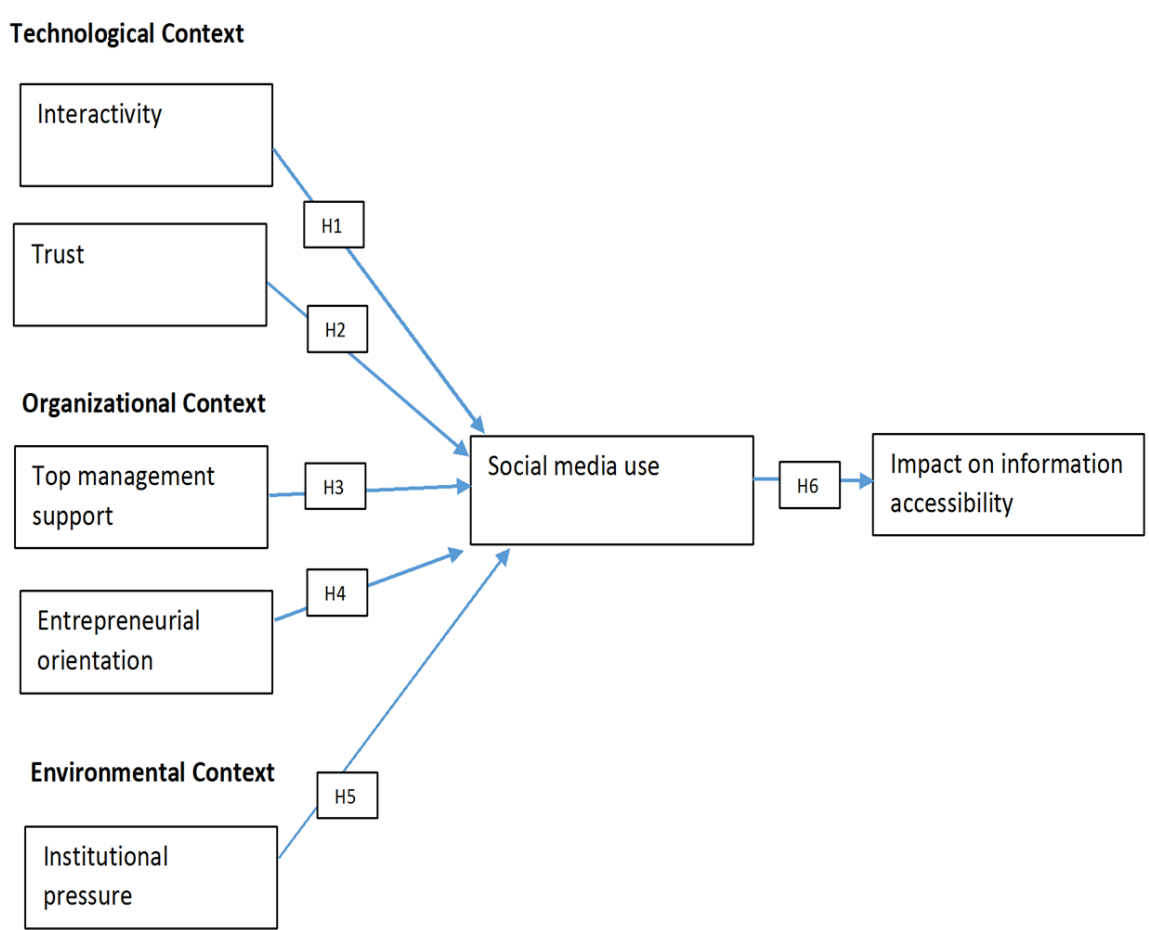

\section{Figure 1 - The Research Model}

\section{Trust and Social Media Usage}

Trust is one of the important factors that were investigated by previous researchers. According to McKnight and Chervany (2002), institutional trust is the subjective belief with which organizational members collectively assess that favorable conditions are in place, and that are conducive to the transaction success. Mcknight et al. (1998) described two types of institution based trust - situational normality and structural assurance. Situational normality refers to the belief that success is anticipated because the situation is normal. Whereas the Structural assurances refer to belief that favorable outcomes are likely because of contextual structures, such as contracts, regulations and guarantees. For this study, trust was included under the technological context, trust on technology especially the structural assurance on the technology service provider or the particular technology features might have an impact on the usage of the technology. In the social media context, the organizations post lot of information about their organization, products, services and other promotional activities. So there might be a need for structural assurance in social media to use it and reach large number of audience. Therefore the impact of trust (structural assurance) on social media usage is examined in this study.

H2: Trust (Structural assurance) on social media positively influences social media usage. 


\section{Top Management Support and Social Media Usage}

For the organizational factors, factors such as top management support and entrepreneurial orientation of the organization were used. Numerous studies have shown the relationship between top management support and technology usage (Chong and Chan, 2012; Ramdani et al., 2009; Low et al., 2011). Social media is like a 'double-edged sword', as it provides many advantages; there are also some disadvantages due to which the top management might hesitate to use social media. Some of the issues related to social media are that social media usage by employees might affect the productivity, as employees spend more time wasting in social media sites. Reputation management is critical when using social media, dissatisfied customers or employees can post information about organization that might affect the reputation of the organization (Shirky, 2008; Zyl, 2009). Moreover, social media usage in an organization also requires continuous monitoring and proper staff to update the information on the site, so proper resources should be provided for the successful usage of social media. Considering all these issues, top management support can be an important factor for the use of social media.

H3: Top management support positively influences social media usage.

\section{Entrepreneurial Orientation and Social Media Usage}

Based on resource-based view theory, entrepreneurial orientation is considered as an important asset for firms competing in electronic environment (Colton et al., 2010). Entrepreneurial orientation is defined as the methods, practices, and decision-making styles managers use to act entrepreneurially. These include processes such as experimenting with promising new technologies, being willing to seize new product-market opportunities, and having a predisposition to undertake risky ventures
(Lumpkin and Dess, 1996). Thus, the established three key elements of this construct are innovativeness, proactiveness, and risk-taking (Covin and Slevin, 1991; Wiklund, 1999). For this study the innovativeness and risk taking propensity of the firm are investigated to determine the influence of entrepreneurial orientation of the firm towards social media usage.

In terms of innovativeness, it is proposed that firms with a high entrepreneurial orientation eagerly embark upon experimentation, support new ideas, and depart from existing practices (Lumpkin and Dess, 1996). Risk-taking element is linked to the company's propensity to engage in projects that have uncertain outcomes or high profits and losses (Lumpkin and Dess, 1996). Not many researchers have studied the direct impact of entrepreneurial orientation on technology adoption; however, some studies have examined the role of entrepreneurial orientation on various aspects of the technology and organizational performances (Elliot and Boshoff, 2005; Mostafa et al., 2006). For technologies like social media which demands open and two-way communications, organizations must be ready to face both positive and negative consequences from the audience. Therefore, entrepreneurial orientation of an organization is an important factor for social media usage.

H4: Entrepreneurial Orientation of the organization positively influences social media usage.

\section{Institutional Pressure and Social Media Usage}

Institutional theory proposes that the institutional environment provides rule-like social expectations and norms for appropriate organizational structures, operations, behaviors, and practices (DiMaggio and Powell, 1983; Meyer and Rowan, 1977; Scott, 1995; Zucker, 1987). Institutional pressure refers to the pressure that emanate from institutional environments that can induce firms to adopt 
shared norms and routines (DiMaggio and Powell, 1983). They categorized institutional pressures into normative, mimetic, and coercive pressures. The agents that may exert pressures include a firm's key customers, suppliers, competitors, and the government (Ke et al., 2009). Based on the interviews that was conducted prior to the survey to identify the key influential and impact factor of social media, the two constructs of institutional pressure are considered for further investigation in this study. Mimetic forces are pressures to copy or emulate other organizations' activities, systems, or structures. Coercive forces are the external pressures exerted by government, regulatory, or other agencies to adopt the structures or systems that they favor. Several studies have taken an institutional approach to study the internet technology usage (Purvis et al., 2001; Chatterjee et al., 2002; Teo et al., 2003; Ke et al., 2009, Liu et al., 2010). Even for social media, it is possible to state that firms are likely to be induced to use social media due to the external pressures.

H5: Institutional pressure positively influences social media usage.

\section{Social media usage and information accessibility}

The construct system usage continues to be developed and tested by IS researchers (Gelderman, 1998; Goodhue and Thompson, 1995; Guimaraes and Igbaria, 1997). Based on DeLone and McLean IS success model, in order to investigate the usage of social media in organizations, the informed effective use of social media was considered, as this was an important indication of technology success, which in turn has an impact on organizations (DeLone and McLean, 2003). The growth of various information technologies is providing various informational benefits to organizations. Mirani and Lederer (1998), in their study divided the Informational benefits into information access, information quality, and information flexibility. One of the most important impacts of social media usage is the improvement in information accessibility; the organizations can get the information about their potential customers from the conversations in the social media sites. Similarly they can also obtain information about their competitors and the industry directly and easily via social media (Parveen et al., 2015). Even though social media provides improvement in informational accessibility, studies investigating this relationship are very limited. Therefore this study attempts to examine the relationship between social media usage and its impact on information accessibility.

H6: Social media usage positively influences the information accessibility of the organizations.

\section{Research Methodology}

For the present study, organizations that are using social media in Malaysia are the target population. The organizations that are using social media were identified by browsing through various organizations' website. The data for this study are gathered over a three-month period from March to May 2014 using the survey method. The unit of analysis for this study is the organization. Additionally, it is also important to determine the respondents representing the unit of analysis (Hair, Bush and Ortinau, 2006). For this study, key organizational informants such as Senior Managers from the corporate communication or marketing department or the Head of social media team are the respondents following the single keyinformant approach, the most commonly used method in organizational research (Kumar, Stern and Anderson, 1993). Table 1 shows the steps taken to identify the sample for the study. 


\begin{tabular}{|c|c|}
\hline Step 1 & $\begin{array}{l}\text { Retrieved lists of Malaysian business organizations from various sources } \\
\text { - Kuala Lumpur Stock Exchange (list of public listed organizations), } \\
\text { - SME Corporation (list of small and medium-sized enterprises), } \\
\text { - MSC Malaysia (list of MSC status companies), } \\
\text { - MARTRADE, the national trade promotion agency of Malaysia (listed } \\
\text { - Top } 1000 \text { Companies Directory }\end{array}$ \\
\hline Step 2 & $\begin{array}{l}\text { - Overall, a list of } 9,918 \text { organizations was retrieved. } \\
\text { - Only } 7,910 \text { organizations were included in the study due to issues such as } \\
\text { website link was not found, or website links were broken or the website was } \\
\text { under construction. }\end{array}$ \\
\hline Step 3 & $\begin{array}{l}\text { - Among the } 7,910 \text { websites researched, only } 664 \text { organizations were using } \\
\text { some kind of social media and thus included for data collection }\end{array}$ \\
\hline
\end{tabular}

Before conducting the survey, interviews were conducted among the senior managers of six organizations that are using social media. Interviews were conducted to identify the purpose of social media usage for information search and the benefits associated with the usage. Factors that influenced social media usage among organizations were also identified. Based on the interview findings and after referring the literature, the identified constructs were included in the study for further investigation. In the survey questionnaire the statements were measured using multiple items, on five-point Likert scale items anchored with, " $1=$ Strongly Disagree" and " $5=$ Strongly Agree". Refer Appendix 2 for the construct definition, items and their sources. Prior to the main survey, pilot test was conducted with 33 responses in order to ensure the validity of the questions and structures. Some minor revision were made and subsequently, the survey was conducted online using Survey Monkey. For data analysis, PLS technique was used to test the hypotheses of the study.

\section{Results}

Among the 664 questionnaires distributed, 171 usable responses were received showing a response rate of $26 \%$. More than half $(53 \%)$ of the organization replied that they have been using social media in their organization for more than 2 years, and about $32 \%$ of the organization have been using it for 1 to 2 years. This showed that most of the organizations in Malaysia have been using social media for a reasonable period of time. Therefore it is possible to study the impact of social media usage on organization. The profile of the responses for this study in terms of industry type, years in operation, and number of employees is summarized in Table 2.

\section{Assessment of Measurement Model}

This study uses the PLS (Partial Least Square) technique to analyse data by using SmartPLS 2.0 software. Figure 2 illustrates the measurement model of the study and the factor loadings (outer loadings) of the constructs. The study uses the two-stage approach. In the first stage, the figure 2 shows that all the first order constructs for instance, coercive pressure (CP), mimetic pressure (MP) of Institutional Pressure construct and Risk Taking propensity (RT), Innovativeness (Inno) from Entrepreneurial Orientation constructs are directly connected with other constructs of the study. 


\begin{tabular}{|l|l|l|}
\hline Table 2 - Organization Profile \\
\begin{tabular}{|l|l|l|}
\hline Type of Industry & Frequency & Percentage \\
\hline Manufacturing & 26 & $15.2 \%$ \\
\hline Services & 145 & $84.8 \%$ \\
\hline Organization Age & Frequency & Percentage \\
\hline Years in Operation & 31 & $18.1 \%$ \\
\hline 5 to 10 Years & 32 & $18.7 \%$ \\
\hline 10 to 15 Years & 23 & $13.5 \%$ \\
\hline 15 to 20 Years & 51 & $29.8 \%$ \\
\hline More than 20 Years & \multicolumn{2}{|l|}{} \\
\hline Number of Employees & Frequency & Percentage \\
\hline No. of Employees & 76 & $44.4 \%$ \\
\hline Less than 50 & 24 & $14 \%$ \\
\hline 50 to 100 & 15 & $8.8 \%$ \\
\hline 100 to 200 & 7 & $4.1 \%$ \\
\hline 200 to 300 & 3 & $1.8 \%$ \\
\hline 300 to 400 & 4 & $2.3 \%$ \\
\hline 400 to 500 & 42 & $24.6 \%$ \\
\hline More than 500 & & \\
\hline
\end{tabular}
\end{tabular}

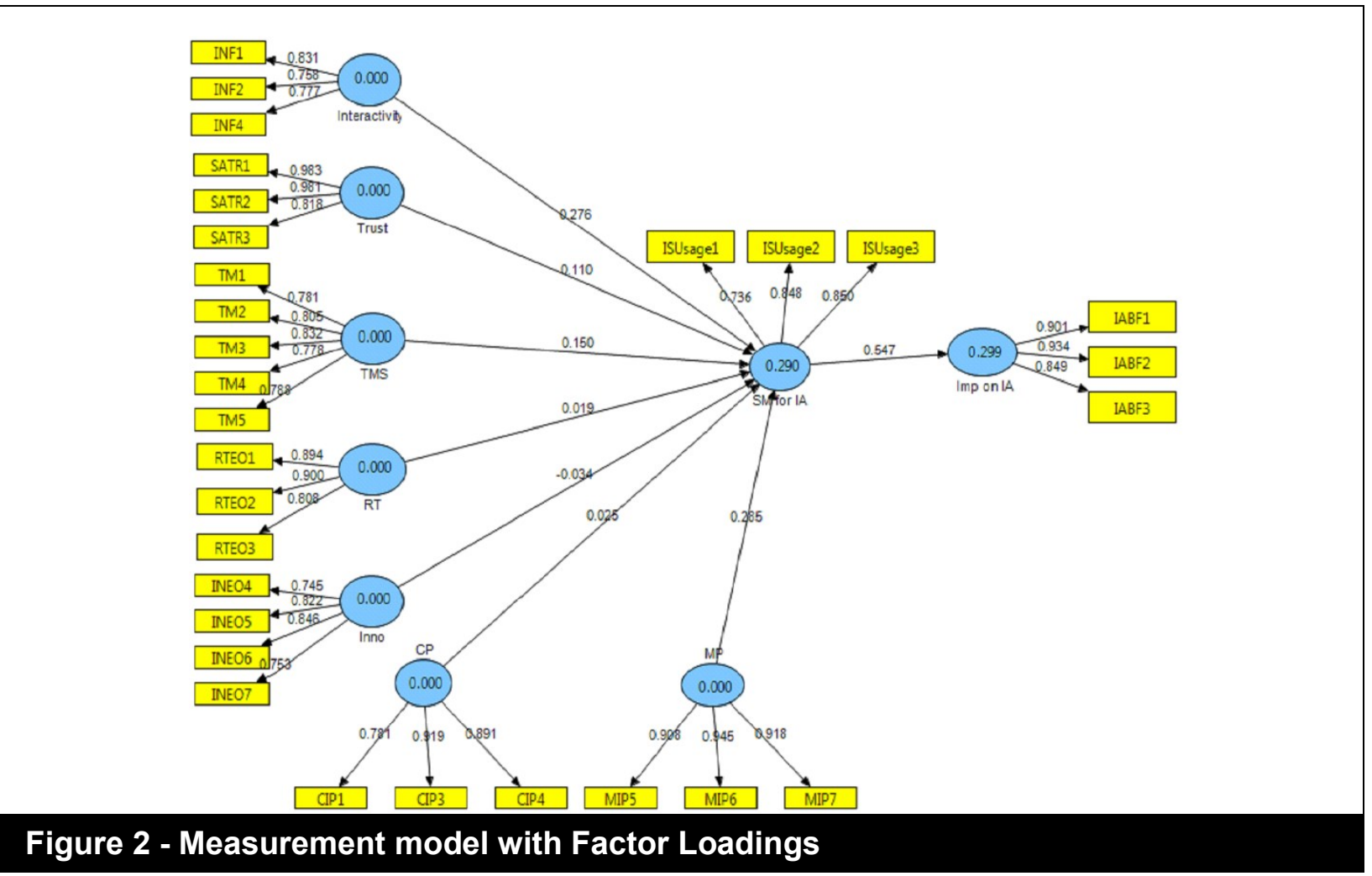


As illustrated in Figure 2, all of the indicators' outer loadings are above the threshold value of 0.708 . Previously, three indicators with low loadings and the deletion of indicators which increased the composite reliability and AVE of the results were removed from the model. An item from interactivity "Social media sites provide an appropriate amount of interactive features (eg. graphics, popup windows, animation, music, voices) was removed from the model as the removal of this item increased the AVE of the construct. Also, an item from the innovativeness construct "Innovation in our company is perceived as too risky and is resisted." was removed from the model due to low loading. Similarly, an item from the impact on information accessibility construct "Social media usage enabled easier access to customer information" was removed from the model due to low loading.

Next in order to test the reliability and validity of the constructs, values of composite reliability and average variance extracted (AVE) are reported in Table 3. Therefore, results of the study revealed that the values of the composite reliability are greater than 0.6 and AVE is greater than 0.5 for all the constructs, thus construct reliability and convergent validity is achieved. The next evaluation criterion for reflective models is to check for discriminant validity. The results of Fornell-Larcker criterion (Refer Appendix 1) showed that that the square root of AVE for the constructs is greater than other interconstructs' correlation value. Therefore this confirms the achievement of discriminant validity.

\section{Table 3 - Construct Reliability and Convergent Validity}

\begin{tabular}{|l|l|l|l|}
\hline Constructs & AVE & Composite Reliability & Cronbachs Alpha \\
\hline Interactivity & 0.623 & 0.832 & 0.705 \\
\hline Trust & 0.866 & 0.950 & 0.921 \\
\hline Top Management Support(TMS) & 0.635 & 0.897 & 0.856 \\
\hline Risk Taking(RT) & 0.754 & 0.901 & 0.837 \\
\hline Innovativeness(Inno) & 0.628 & 0.871 & 0.806 \\
\hline Coercive Pressure(CP) & 0.749 & 0.899 & 0.832 \\
\hline Mimetic Pressure(MP) & 0.853 & 0.945 & 0.914 \\
\hline SM for IA & 0.544 & 0.769 & 0.659 \\
\hline Imp on IA & 0.801 & 0.923 & 0.878 \\
\hline
\end{tabular}

\section{Evaluation of Second Order Constructs}

The evaluation of second order constructs is similar to the assessment of first order constructs. This study modeled two second order constructs namely institutional pressure which has two first order constructs; coercive and mimetic pressures; entrepreneurial orientation with risk taking propensity and innovativeness as first order constructs. During the $2^{\text {nd }}$ stage of analysis, the Latent Variable Scores (LVS) of first order constructs were used as indicators for second order constructs. The composite reliability, AVE, and outer loadings were evaluated for the second order constructs during $2^{\text {nd }}$ stage of analysis. Table 4 summarizes the evaluation results of the second order constructs. 


\section{Table 4 - Evaluation of Second Order Constructs}

\begin{tabular}{|l|l|l|l|}
\hline Constructs/Indicators & AVE & Composite Reliability & Outer Loadings \\
\hline Institutional Pressure & 0.825 & 0.904 & - \\
\hline Coercive Pressure(CP) & - & - & 0.890 \\
\hline Mimetic Pressure(MP) & - & - & 0.926 \\
\hline Entrepreneurial Orientation & 0.726 & 0.841 & - \\
\hline Risk taking(RT) & - & - & 0.865 \\
\hline Innovativeness(Inno) & - & - & 0.839 \\
\hline
\end{tabular}

The results report the composite reliability and AVE of only the second order constructs, as the first order constructs have been evaluated previously. The AVE of institutional pressure was 0.8257 and entrepreneurial orientation was 0.7268 . The AVE values of the second order constructs were well above the cut-off value 0.5 . The composite reliability of institutional pressure was 0.9045 and entrepreneurial orientation was 0.8418 . The reliability values are above the threshold of 0.70 thus supporting internal consistency reliability. The outer loadings of the indicators of second order constructs were well above the critical value of 0.70 .

\section{Assessment of Structural Model}

The important criterion to assess the structural model was the estimates of path coefficients and $R^{2}$. The estimated values for path relationships in the structural model should be evaluated in terms of sign and magnitude. The significance of the hypothesized relationship was estimated through bootstrapping. Figure 3 shows the structural model with path coefficients, $t$ values and $R^{2}$ value.

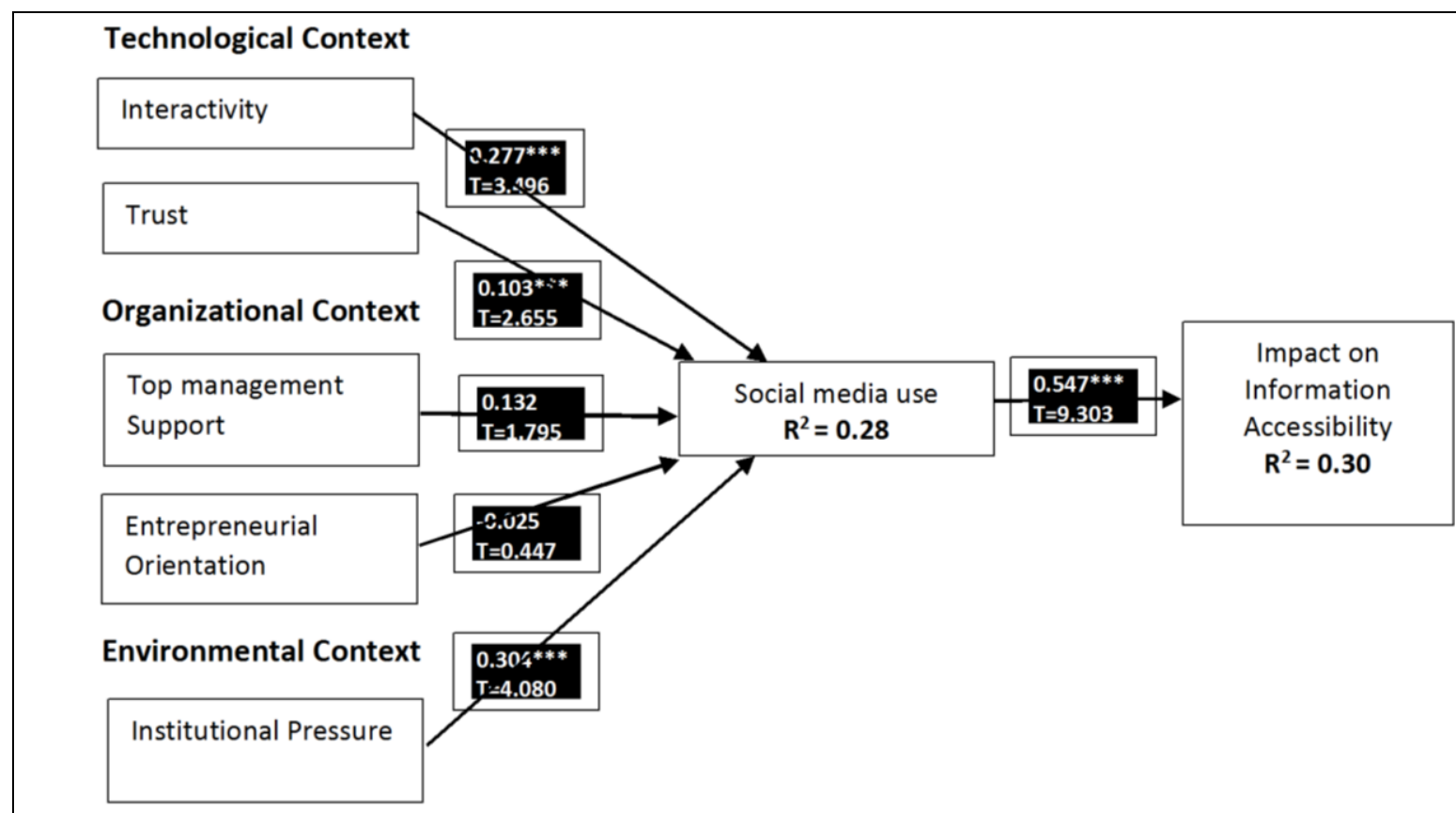

Figure 3 - Assessment of Structural Model

Notes: ${ }^{* * *} p<0.01(>2.58),{ }^{* *} p<0.05(>1.96), p<0.10(>1.645)$ 
The main criterions to assess the structural models are the $R^{2}$ of endogenous latent values. This study shows the $R^{2}$ value for the endogenous latent variables social media usage was 0.28 and impact on information accessibility was 0.30 , which are considered as slightly moderate. The result of the path coefficients and t-values (Table 5) showed that interactivity, trust and institutional pressure with t-value $>2.67$ at $1 \%$ significance level significantly influence social media usage among organizations. Similarly, social media usage with t- value $>2.67$ at $1 \%$ significance level have an impact on informational accessibility. Therefore $\mathrm{H} 1, \mathrm{H} 2, \mathrm{H} 5$ and $\mathrm{H} 6$ are supported in the study. Table 5 summarizes the results of Hypotheses testing.

\begin{tabular}{|c|c|c|c|}
\hline Hypotheses & Beta & $\begin{array}{l}\text { T- } \\
\text { value }\end{array}$ & Result \\
\hline $\begin{array}{l}\text { H1: Interactivity of social media positively influences social media } \\
\text { usage }\end{array}$ & $0.277^{* * *}$ & 3.496 & Supported \\
\hline H2: Trust on social media positively influences social media usage & $0.103^{* * *}$ & 2.655 & Supported \\
\hline $\begin{array}{l}\text { H3: Top management support positively influences social media } \\
\text { usage }\end{array}$ & 0.132 & 1.795 & $\begin{array}{l}\text { Not } \\
\text { Supported }\end{array}$ \\
\hline $\begin{array}{l}\text { H4: Entrepreneurial orientation positively influences social media } \\
\text { usage }\end{array}$ & -0.025 & 0.447 & $\begin{array}{l}\text { Not } \\
\text { Supported }\end{array}$ \\
\hline H5: Institutional pressure positively influences social media usage & $0.304^{* * *}$ & 4.080 & Supported \\
\hline $\begin{array}{l}\text { H6: Social media usage will have a positive impact on information } \\
\text { accessibility }\end{array}$ & $0.547^{* * *}$ & 9.303 & Supported \\
\hline
\end{tabular}

\section{Discussion and Conclusion}

Findings of the study suggested that interactivity, trust and institutional pressures are significantly related to social media usage. On the contrary, entrepreneurial orientation and top management support were not significantly related to social media usage. The results also showed that social media usage had a positive impact on information accessibility. The results revealed that interactivity of social media is an important factor that determined social media use in organizations $(P<0.01)$. Interaction between the public and the organizations can be improved tremendously by the interactive nature of social media which influences the organizations to adopt social media. After adoption, the interactivity aspect of the technology motivates them to use it more effectively as they can interact with customers and receives feedback in a timely manner which helps to improve their business. Previous studies also provided consistent results that interactivity of the technology has a strong effect on technology usage (Lee and Kozar, 2012; Pituch and Lee, 2006). Similarly, trust was found to have significant relationship with social media usage. The organizations post lot of information about their products, services and other promotional activities on social media sites. So trust in terms of structural assurance on social media technologies is an influential factor for its effective usage in organizations. The result is consistent with Chai et al. (2011) who founded that trust is an important factor that influences the knowledge sharing behaviors in blogs. Therefore this study found that trust on social media influences the social media usage in organizations.

Another important determinant of social media usage is the institutional pressure that emanated from the external environment $(P<0.01)$. The explanation for the result could be that pressure from 
various external parties such as competitors and customers had a positive influence on the organizations' usage of social media. Since the competitors and customers are also very active in social media, it pressures the organizations to use social media effectively to communicate with them and to keep up with the trend. The finding of this study is consistent with previous studies that argued that institutional pressure was an important determinant of technology usage (Teo et al., 2003; Ke et al., 2009, Liang et al., 2007). However, top management support was not a significant factor that influences social media usage in organizations. This result contradicted with most of the previous studies' findings which stated that top management support is an important determinant of technology usage (Chong and Chan, 2012; Ramdani et al., 2009; Low et al., 2011; Ifinedo, 2011; Scupola, 2009). However, the result is consistent with Wang et al. (2010)'s study which found that top management support is not a significant factor for technology usage. Due to the reputation issues associated with social media, the top management might be reluctant to use social media and does not provide complete support. For some organizations, considering the positives of social media the organizations do have social media presence but don't use it effectively due to the lack of funds segregated by top managements to monitor social media usage in organizations.

The last insignificant factor was the entrepreneurial orientation of the firm. Not many studies have investigated the direct relationship between entrepreneurial orientation and technology usage. However, similar to the study findings, Urban (2010) in his study found that entrepreneurial orientation was not significantly associated with technology orientation of the organization. In addition, Colton et al. (2010) examined the role of entrepreneurial orientation in e-tailing context and found that entrepreneurial orientation does not have a positive impact on brand strength in e-tailing. The explanation for the insignificant result would be that social media is not a big investment which involves great risk. So the risk taking propensity might not be an important factor in the usage of social media. Moreover the organizations need not have to be very innovative to use social media; even a sole proprietor who has a small business and sells basic goods may use social media to advertise his products and services. Therefore, entrepreneurial orientation of the firm does not play an important role in social media adoption. The results also revealed that social media usage has a positive influence on information accessibility. Organizations can get information about their potential customers, their tastes, their wants easily from the conversations in the social media sites such as Facebook pages, twitter sites etc., By becoming a fan of other organizations' Facebook pages, it enables them to retrieve more information about their competitors, their activities, their tactics, and their brand sentiments which helps them to enhance their products and services in order to achieve greater impact on organizations' performance.

\section{Implications of the Study}

Literature on Information Technology stated that studies examining the determinants of IT use, the extent of IT use and firm performance in an integrative model was sparse (Devaraj and Kohli, 2003). However, during the past few years, studies have been conducted to investigate the antecedents and consequences of various IT systems (Lee et al., 2010; Salwani et al., 2009; Stone et al., 2007; Zhu and Kraemer, 2005). But in the context of social media, there is a lack of studies that investigated the organizational usage of social media in an integrated model (Akar and Topcu, 2011; Lovejoy and Saxton, 2012). Therefore the current study using an integrative model examined the determinants of social media use, the purpose of social media use and its impact. 
This study investigated various factors to study its influence on social media usage. Previous studies that used TOE framework have mostly used general technological factors to study its influence on technology usage in organizations. However considering the interactive nature of social media, this study used social media specific variable such as social media interactivity to study its influence on social media usage. Similarly for organizational context, previous studies used descriptive measures such as the firm's size and scope, centralization, formalization, and complexity of managerial structure, the quality of human resource, and the amount of internal slack resources. This study rather than considering the descriptive measures, investigated the influence of entrepreneurial orientations of the firm on technology usage. Therefore this study validates and provides more support to the TOE framework. Apart from the commonly used constructs, constructs such as interactivity and entrepreneurial orientation were added to the framework to enhance it and make it more appropriate to study the web 2.0 technologies and upcoming new technologies that are highly collaborative and interactive.

Moreover, this study illustrated the use of social media for information search and subsequently its impact on easier access to information from various sources. Thus the obtained information via social media would enable the organization to have better knowledge about the customers, competitors and the market in general which helps the organizations to enhance the existing services and also to develop new products and services that are up-to-date. At the same time, this study only investigated the impact of social media on information accessibility. There may be other benefits associated with the use of social media in the organizational context which were not examined in this study. This study investigated the usage of social media considering all the social media tools in general. Since each social media tool has unique features and provides different benefits; future studies should concentrate on one social media tool in particular and investigate it in detail, which might provide a more complete understanding of the particular social media tools' impact on organizations.

\section{References}

Agarwal, R. and Venkatesh, V. (2002). "Assessing a firm's web presence: a heuristic evaluation procedure for the measurement of usability". Information Systems Research, 13(2), pp.168-186.

Akar, E. and Topcu, B. (2011). "An examination of the factors influencing consumers' attitudes toward social media marketing". Journal of Internet Commerce, 10(1), pp. 35-67.

Al-Qirim, N. (2007). "The adoption of eCommerce communications and applications technologies in small businesses in New Zealand". Electronic Commerce Research and Applications, 6(4), pp. 462-473.

doi: http://dx.doi.org/10.1016/j.elerap.2 007.02 .012

Cairncross, F. (2001). The death of distance: 2.0: how the communications revolution will change our lives: Texere.

Chai, S., Das, S. and Rao, H. R. (2011). "Factors affecting bloggers' knowledge sharing: An investigation across gender". Journal of Management Information Systems, 28(3), pp. 309-342.

Chatterjee, D., Grewal, R. and Sambamurthy, V. (2002). "Shaping up for e-commerce: institutional enablers of the organizational assimilation of web technologies". MIS Quarterly, 6589.

Chong, A. Y.-L. and Chan, F. T. (2012). "Structural equation modeling for 
Role of Social Media on Information Accessibility / Tajudeen et al.

multi-stage analysis on Radio Frequency Identification (RFID) diffusion in the health care industry". Expert Systems with Applications, 39(10), pp. 8645-8654.

Chu, S. K. W., Woo, M., King, R. B., Choi, S., Cheng, M. and Doo, P. (2011). "Examining the application of Web 2.0 in medical related organizations". Health Information and Libraries Journal, 29, pp.47-60.

Colton, D., A., Roth, M., S. and Bearden, W. O. (2010). "Drivers of International ETail Performance: The Complexities of Orientations and Resources". Journal of International Marketing, 18(1), pp.122.

Covin, J. G. and Slevin, D. P. (1989). "Strategic management of small firms in hostile and benign environments". Strategic management journal, 10(1), pp. 75-87.

Covin, J. and Slevin, D. (1991). "A Conceptual model of entrepreneurship as firm behaviour". Entrepreneur Theory and Practice, 16(1), pp.7-25.

DeLone, W. H. and McLean, E. R. (2003). "The DeLone and McLean model of information systems success: a ten year update". Journal of Management Information Systems, 19(4), pp. 9-30.

DePietro, R., Wiarda, E. and Fleischer, M. (1990). "The context for change: organization, technology and environment". In L. G. Tornatzky \& M. Fleischer (Eds.), The Process of technological innovation (pp. 151175). Lexington Books, Lexington.

Devaraj, S. and Kohli, R. (2003). "Performance impacts of information technology: is actual usage the missing link?" Management science, 49(3), pp. 273-289.

DiMaggio, P. J. and Powell, W. W. (1983). "The iron cage revisited - Institutional Isomorphism and Collective
Rationality in Organisational Fields". American Sociological Review, 48(2), pp. 147-160.

Elliot, R. and Boshoff, C. (2005). "The influence of organisational factors in small tourism businesses on the success of internet marketing". Management Dynamics, 14(3), pp. 4458.

Gelderman, M. (1998). "The relation between user satisfaction, usage of information systems and performance". Information \& Management, 34(1), pp. 11-18.

Gomez Vasquez, L. M. and Soto Velez, I. (2011). "Social Media as a strategic tool for Corporate Communication.Los Medios Sociales como una Herramienta Estratégica para la Comunicación Corporativa". Revista Internacional de Relaciones Públicas, 1 (2 (jul-dic)), pp. 157-174.

Goodhue, D. L. and Thompson, R. L. (1995). "Task-technology fit and individual performance". MIS quarterly, 19(2), pp. 213-236.

Guimaraes, T. and Igbaria, M. (1997). "Client/server system success: Exploring the human side". Decision Sciences, 28(4), pp. 851-875.

Hair, J., Bush, R., \& Ortinau, D. (2006). Marketing Research within a changing environment. Revised international edition. McGraw-Hill, New York, USA, 589, 566.

Hult, G. T. M., Hurley, R. F. and Knight, G. A. (2004). "Innovativeness: its antecedents and impact on business performance". Industrial marketing management, 33(5), pp. 429-438.

IBM. (2007). "Achieving tangible business benefits with social computing". Retrieved 13 February, 2011, from www.2dnet.co.uk/i/25/ads/whitepapers /IBM/yellow_fewer_new/socialnetworki ng.pdf 
Ifinedo, P. (2011). "Internet/e-business technologies acceptance in Canada's SMEs: an exploratory investigation". Internet Research, 21(3), pp. 255-281.

Jiang, Z. and Benbasat, I. (2007). "Investigating the Influence of the Functional Mechanisms of Online Product Presentations". Information Systems Research, 18(4), pp. 454470.

Ke, W., Liu, H., Wei, K. K., Gu, J. and Chen, H. (2009). "How do mediated and non-mediated power affect electronic supply chain management system adoption? The mediating effects of trust and institutional pressures". Decision Support Systems, 46(4), pp. 839-851.

Khalifa, M. and Davison, M. (2006). "SME adoption of IT: the case of electronic trading systems. Engineering Management", IEEE Transactions on, 53(2), pp. 275-284.

Kumar, N., Stern, L. W. and Anderson, J. C. (1993). "Conducting Interorganizational Research Using Key Informants". The Academy of Management Journal, 36(6), pp. 16331651. doi: $10.2307 / 256824$

Leader-Chivée, L. and Cowan, E. (2008). "Networking the Way to Success: Online Social Networks for Workplace and Competitive Advantage". People \& Strategy, 31, pp. 40-46.

Lee, C.-L., Yen, D. C., Peng, K.-C. and Wu, H.-C. (2010). "The Influence of change agents' behavioral intention on the usage of the activity based costing/management system and firm performance: The perspective of unified theory of acceptance and use of technology". Advances in Accounting, incorporating Advances in International Accounting, 26, pp. 314324.
Lee, Y. and Kozar, K. (2012). "Developing a Theory of Website Usability: An Exploratory Study to Identify Constructs and Nomological Networks". Decision Support Systems, 52(2), pp. 450-463.

Liang, H., Saraf, N., Hu, Q. and Xue, Y. (2007). "Assimilation of enterprise systems: the effect of institutional pressures and the mediating role of top management". MIS Quarterly, 31(1), pp. 59-87.

Liu, H., Ke, W., Wei, K. K., Gu, J. and Chen, H. (2010). "The role of institutional pressures and organizational culture in the firm's intention to adopt internetenabled supply chain management systems". Journal of Operations Management, 28(5), pp. 372-384.

Lovejoy, K. and Saxton, G. D. (2012). "Information, Community, and Action: How Nonprofit Organizations Use Social Media". Journal of ComputerMediated Communication, 17(3), pp. 337-353.

Low, C., Chen, Y. and Wu, M. (2011). "Understanding the determinants of cloud computing adoption". Industrial Management \& Data Systems, 111(7), pp. 1006-1023.

Lumpkin, G. T. and Dess, G. G. (1996). "Clarifying the entrepreneurial orientation construct and linking it to performance". Academy of management Review, 21(1), pp. 135172.

Mangold, W. G. and Faulds, D. J. (2009). "Social media: The new hybrid element of the promotion mix". Business horizons, 52(4), pp. 357-365.

Mayfield, A. (2008). "What is social media?" Retrieved 12th July, 2011, from http://www.icrossing.co.uk

McKnight, D. H. and Chervany, N. (2002). "What trust means in e-commerce 
Role of Social Media on Information Accessibility / Tajudeen et al.

customer relationships: An interdisciplinary conceptual typology". International Journal of Electronic Commerce, 6(2), pp. 35-59.

McKnight, D. H., Cummings, L. L. and Chervany, N. L. (1998). "Initial trust formation in new organizational relationships". Academy of Management review, 23(3), pp. 473490.

Meyer, J. W. and Rowan, B. (1977). "Institutionalized organizations: Formal structure as myth and ceremony". American journal of sociology, 83(2), pp. 340-363.

Mirani, R. and Lederer, A. L. (1998). "An instrument for assessing the organizational benefits of IS projects". Decision Sciences, 29(4), pp. 803-838.

Moen, Ø., Madsen, T. K. and Aspelund, A. (2008). "The importance of the internet in international business-tobusiness markets". International Marketing Review, 25(5), pp. 487-503.

Mostafa, R. H., Wheeler, C. and Jones, M. V. (2006). "Entrepreneurial orientation, commitment to the Internet and export performance in small and medium sized exporting firms". Journal of International Entrepreneurship, 3(4), pp. 291-302.

Naman, J. L. and Slevin, D. P. (1993). "Entrepreneurship and the concept of fit: a model and empirical tests". Strategic management journal, 14(2), pp. 137-153.

Parveen, F., Jaafar, N. I. and Ainin, S. (2015). "Social media usage and organizational performance: Reflections of Malaysian social media managers". Telematics and Informatics, 32(1), pp. 67-78.

Papastathopoulou, P. and Avlonitis, G. J. (2009). "Classifying enterprises on the basis of WWW use: a behavioral approach". Internet Research, 19(3), pp. 332-347.

Pituch, K. A. and Lee, Y.-k. (2006). "The influence of system characteristics on e-learning use". Computers \& Education, 47(2), pp. 222-244.

Purvis, R. L., Sambamurthy, V. and Zmud, R. W. (2001). "The assimilation of knowledge platforms in organizations: An empirical investigation". Organization science, 12(2), pp. 117135.

Ramdani, B., Kawalek, P. and Lorenzo, O. (2009). "Predicting SMEs' adoption of enterprise systems". Journal of Enterprise Information Management, 22(1/2), pp. 10-24.

Rashtcy, F., Kessler, A. M., Bieber, P. J., Shindler, N. H. and Tzeng, J. C. (2007). The user revolution: The new advertising ecosystem and the rise of the Internet as a mass medium. Piper Jaffray Investment Research, Minneapolis, MN.

Robertson, R. A. (2005). "A framework of critical drivers in successful businessto-business e-commerce". Proceedings of the Southeast Conference, IEEEPaper presented at the Southeast Conference Proceedings, IEEE, 378-383. doi: 10.1109/SECON.2005.1423276

Salwani, M. I., Marthandan, G., Norzaidi, M. D. and Chong, S. C. (2009). "ECommerce usage and business performance in the Malaysian tourism sector: empirical analysis". Information Management \& Computer Security, 17(2), pp. 166-185.

Schultz, R. J., Schwepker Jr, C. H. and Good, D. J. (2012). "Social media usage: an investigation of $\mathrm{B} 2 \mathrm{~B}$ salespeople". American Journal of Business, 27(2), pp. 174-194.

Scott, W. R. (1995). Institutions and Organizations. Sage Pub, Thousand Oaks, CA. 
Scupola, A. (2009). "SME's e-commerce adoption: perspectives from Denmark and Australia". Journal of Enterprise Information Management, 22(1), pp. $152-166$.

Shirky, C. (2008). Here Comes Everybody. The Power of Organising without Organisations. Penguin Books, New York, NY

Stone, R. W., Good, D. J. and BakerEveleth, L. (2007). "The impact of information technology on individual and firm marketing performance". Behaviour \& Information Technology, 26(6), pp. 465-482.

Teo, H.-H., Wei, K. K. and Benbasat, I. (2003). "Predicting intention to adopt interorganizational linkages: an institutional perspective". MIS Quarterly, 21(1), pp. 19-49.

Teo, T. S. and Pian, Y. (2003). "A contingency perspective on Internet adoption and competitive advantage". European Journal of Information Systems, 12(2), pp. 78-92.

Thong, J. Y., Yap, C.-S., and Raman, K. (1996). "Top management support, external expertise and information systems implementation in small businesses". Information systems research, 7(2), pp. 248-267.

Tornatzky, L. and Fleischer, M. (1990). The process of technology innovation. Lexington Books, Lexington, MA.

Trainor, K. J. (2012). "Relating social media technologies to performance: a capabilities-based perspective". Journal of Personal Selling and Sales Management 32(3), pp. 317-331.

Unic'ersalMcCann. (2008). "Power to the people social media tracker". Wave 3 . Retrieved 5th July, 2012, from http://www.universalmccann.com/Ass ets/wave_3_20080403093750.pdf
Urban, B. (2010). "Technology and entrepreneurial orientation at the organisational level in the Johannesburg area". SA Journal of Human Resource Management/SA Tydskrif vir Menslikehulpbronbestuur, 8(1), pp.9. doi: 10.4102/sajhrm.v8i1.212

VanBoskirk, S., Overby, C. S. and Takvorian, S. (2011). "U.S. Interactive Marketing Forecast, 2011 to 2016". Forrester Research, Cambridge, MA.

Wang, Y.-M., Wang, Y.-S. and Yang, Y.-F. (2010). "Understanding the determinants of RFID adoption in the manufacturing industry". Technological Forecasting and Social Change, 77(5), pp. 803-815.

Wiklund, J. (1999). "The sustainability of the entrepreneurial orientation-performace relationship". Entrepreneur Theory and Practice, 24(1), pp. 37-48.

Zhu, K. and Kraemer, K. L. (2005). "Postadoption variations in usage and value of e-business by organizations: crosscountry evidence from the retail industry". Information Systems Research, 16(1), pp. 61-84.

Zucker, L. G. (1987). "Institutional theories of organization". Annual review of sociology, 13, pp. 443-464.

Zyl, A. S. V. (2009). "The impact of Social Networking 2.0 on organisations". Electronic Library, The, 27(6), pp. 906-918.

doi: $10.1108 / 02640470911004020$ 


\section{Appendix 1 - Fornell-Larcker criterion}

\begin{tabular}{|l|l|l|l|l|l|l|l|l|l|}
\hline & $\mathbf{C P}$ & $\begin{array}{l}\text { Imp on } \\
\text { IA }\end{array}$ & \multicolumn{1}{|c|}{ Inno } & Interactivity & MP & RT & SM for IA & TMS & Trust \\
\hline CP & 0.866 & & & & & & & & \\
\hline Imp on IA & 0.536 & 0.895 & & & & & & & \\
\hline Inno & 0.313 & 0.375 & 0.793 & & & & & & \\
\hline Interactivity & 0.244 & 0.439 & 0.436 & 0.789 & & & & & \\
\hline MP & 0.654 & 0.582 & 0.203 & 0.246 & 0.924 & & & & \\
\hline RT & 0.422 & 0.371 & 0.454 & 0.280 & 0.354 & 0.868 & & & \\
\hline SM for IA & 0.348 & 0.547 & 0.226 & 0.386 & 0.423 & 0.245 & 0.738 & & \\
\hline TMS & 0.507 & 0.460 & 0.475 & 0.373 & 0.420 & 0.390 & 0.363 & 0.797 & \\
\hline Trust & -0.041 & -0.131 & -0.059 & -0.122 & -0.088 & -0.050 & 0.031 & -0.132 & 0.931 \\
\hline
\end{tabular}

\section{Appendix 2 - Constructs, Measures and Sources}

\section{Social media Interactivity \\ Social media interactivity is conceptualized as the website's ability to create vivid interaction and communication with users (Lee and Kozar, 2012).}

\section{Trust (Structural Assurance)}

Structural assurance is conceptualized in this study as the belief that favorable outcomes are likely because of contextual structures, such as contracts, regulations, and guarantees (McKnight et al., 1998).

\section{Top management Support}

Top management support refers to the involvement, enthusiasm, motivation, and encouragement provided by management towards the acceptance of IS innovations Items

- Interactive features of the social media sites that my organization use (e.g., Facebook and twitter) are vivid and evoke responses.

- The social media sites provide features for interactive communication with our customers.

- The social media sites provide an appropriate amount of interactive features (e.g., graphics, pop-up windows, animation, music, voices).

- The social media sites contain components to help the interaction between it and consumers.

\section{Items}

- The Social media sites (e.g., Facebook, twitter) that my organization uses provide enough safeguards to make us feel comfortable using it to post our organization's information.

- The Social media sites (e.g., Facebook, twitter) that my organization uses provide a robust and safe environment in which to transact our information.

- Our organization feel assured that legal and technological structures adequately protect us from problems on the social media.

\begin{tabular}{|cl|ll|}
\hline Items & Source \\
\hline $\begin{array}{l}\text { Top management considers Social } \\
\text { media adoption as important to the } \\
\text { organization. }\end{array}$ & $\begin{array}{l}\text { Teo and Pian, } \\
(2003)\end{array}$ \\
\hline $\begin{array}{l}\text { Top management effectively } \\
\text { communicates its support for the }\end{array}$ & $\begin{array}{l}\text { Chong and Chan, } \\
(2012)\end{array}$ \\
\hline
\end{tabular}

Source

Lee and Kozar, (2012)

\section{Source} Rao, (2011)
Chai, Das, and 
(Thong, Yap and Raman, 1996; Chatterjee et al., 2002; Al-Qirim, 2007; Ramdani et al., 2009). use of Social media

- Top management is likely to invest funds in social media technology

- Top management had established goals and standards to monitor the social media usage in organization.

\begin{tabular}{l}
\hline Entrepreneurial orientation \\
\hline Covin and Slevin (1991) \\
described an entrepreneurial \\
orientation as a dimension of \\
strategic posture represented by a \\
firm's risk-taking propensity, \\
tendency to act in competitively \\
aggressive, proactive manners, \\
and reliance on frequent and \\
extensive product innovation.
\end{tabular}
Items

- To seek the sales growth, our company is willing to execute some risky projects

- Even though the costs for some projects are high, under some conditions, our company will still launch those projects

- Our company can accept the uncertainties existing in the projects

- Our company frequently tries out new ideas

- Our company seeks out new ways to do things

- Our company is creative in its methods of operation

- Our company is often the first to do marketing for new products and services

- Innovation in our company is perceived as too risky and is resisted.

\begin{tabular}{l}
\hline Institutional pressure \\
Institutional pressure is the \\
pressure that arises from \\
institutional environments that can \\
induce organizations to adopt \\
shared norms and routines \\
(DiMaggio and Powell, 1983).
\end{tabular}

Items

- Our main customers that matter to us believe that we should use Social media.

- We may not retain our important customers without Social media

- Our main suppliers that matter to us believe that we should use social media

- Our suppliers that are crucial to us wish us to use Social media.

- Our main competitors that have adopted Social media benefited greatly.

- Our main competitors that have adopted Social media are perceived favourably by customers.

Social media usage
Social media used for information
search is considered in this study
Items

- Social media is used to search for general information

- Social media is used to search for competitor information

- Social media is used to search for customer information.
Wang et al., (2010)

Liang et al., (2007)

Source

Covin and Slevin, (1989), Naman and Slevin, (1993) and Hult et al., (2004)

\section{Source}

Teo et al., (2003), Khalifa and Davison, (2006), Liu et al., (2010)

\section{Source}

Papastathopoulou and Avlonitis, (2009), Elliot and Boshoff, (2005) and Moen et al., (2008)

\section{Source}


Role of Social Media on Information Accessibility / Tajudeen et al.

\begin{tabular}{|l|r|l|l|}
\hline accessibility & \multicolumn{2}{|c|}{} \\
\hline $\begin{array}{l}\text { Social media impact on } \\
\text { information accessibility } \\
\text { considered in this study }\end{array}$ & $\begin{array}{l}\text { Enabled easier access to customer } \\
\text { information }\end{array}$ & $\begin{array}{l}\text { Elliot and Boshoff, } \\
\text { (2005), Mirani and } \\
\text { Lederer, (1998) }\end{array}$ \\
\cline { 2 - 3 } & $\begin{array}{l}\text { Enabled easier access to } \\
\text { competitor information }\end{array}$ & $\begin{array}{l}\text { Enabled easier access to market } \\
\text { information }\end{array}$ \\
\cline { 2 - 3 } & $\begin{array}{l}\text { Enabled faster delivery of business } \\
\text { information to customers. }\end{array}$ & \\
\hline
\end{tabular}

\section{About the Authors}

Farzana Parveen Tajudeen is a Senior Lecturer at the Department of Operations and Management Information Systems in University of Malaya's Faculty of Business and Accountancy, Malaysia. Her areas of interest include Social media, Technology adoption and Organizational Performance.

Noor Ismawati Jaafar is an Associate Professor and the Head of the Department of Operations and Management Information Systems in University of Malaya's Faculty of Business and Accountancy, Malaysia. Her areas of interest include IT management, IT governance and Human computer interaction.

Ainin Sulaiman is a Professor at the Department of Operations and Management Information Systems in University of Malaya's Faculty of Business and Accountancy, Malaysia. Her areas of interest include Social Network sites, Information Technology Management and Performance. 